\title{
Relatos de viajes. Hacia la historia y la memoria
}

\author{
Gilda Waldman M. \\ Universidad Nacional Autónoma de México \\ waldman99@yahoo.com
}

La literatura de viajes es un género de larga data en la historia de la cultura occidental, en particular desde la modernidad iniciada en el siglo XVIII, pero que ha experimentado un importante auge en las últimas décadas en el marco de las migraciones y desplazamientos que caracterizan al paisaje contemporáneo. Este artículo analiza dos textos de narrativa de viajes publicados en Chile por las escritoras Cynthia Rimsky (Poste Restante) y Guadalupe Santa Cruz (Quebrada. La cordillera en andas) a la luz de algunos de los temas inscritos en los itinerarios más problemáticos de la reflexión contemporánea: el viaje como metáfora para repensar la cultura de nuestros tiempos, el desarraigo como destino del mundo, la compleja relación entre identidad, pertenencia y hogar, el movimiento como desplazamiento entre una morada inicial y la promesa ¿imposible? de una vuelta a casa, las incertidumbres como condición de vida cuando las viejas certeza se quiebran para dar paso a resultados inciertos, el imperativo de repensar tiempos y espacios más allá de la pertenencia única a una cultura, lenguaje o tradición y, ciertamente, el tema de la escritura como viaje.

Palabras clave: Viaje, escritura, subjetividad, memoria, identidad.

Travel literature as a literary genre has a long history in western culture, especially since the eighteenth century; however, it has had a boom in the last few decades due to the multiple contemporary migrations. This article analyses two narrative works of travel literature published in Chile by Cynthia Rimsky (Poste Restante) and Guadalupe Santa Cruz (Quebrada. La cordillera en andas) taking into account some of the most problematic themes of contemporary thought: travelling as a metaphor to represent the culture of our times, uprooting as the world's destiny, the complex relationship between identity, belonging and home, movement as displacement between an initial home and the perhaps impossible promise of a return, uncertainties as lifestyle when the old certainties have broken and opened way to vague results, the imperative of representing time and space beyond belonging to a unique culture, language or tradition and, definitely, writing as a journey.

Keywords: Travels, Writing, Subjectivity, Memory, Identity.

Recibido: 6 de julio de 2013

Aceptado: 2 de septiembre de 2013 


\section{Los inicios: una partida y una llegada}

Quizá incluso antes de que la palabra se plasmara en escritura, es posible suponer que alguien relató algún viaje a tierras lejanas describiendo los peligros corridos en la aventura y el encuentro con un "otro" desconocido y ajeno a la propia tribu. Cuando la herencia oral se convirtió en texto, el viaje como motivo literario se hizo presente, por ejemplo, en el mítico regreso de Ulises a Odisea, en los viajes de Dante por el infierno, el purgatorio y el paraíso; en la travesía de don Quijote por La Mancha, en los viajes de Gulliver por Liliput y Brobdingnag, en la expedición del capitán Ahab tras la ballena blanca, en el recorrido por el mundo en ochenta días del aristócrata Phileas Fogg, en el viaje de Marlowe por el Congo belga, o en la aventura del innombrado protagonista de Los pasos perdidos por el Orinoco. Asimismo, escritores como Flaubert, Malraux, Bowles, Hemingway, Durrell y Orwell, entre otros, relataron en varios de sus libros sus vivencias alrededor del mundo o utilizaron el viaje como inspiración. Pero también fueron muchos los viajeros que, por razones diversas, registraron por escrito sus experiencias a medida que se desplazaban entre un lugar de partida y otro de llegada explorando nuevas realidades geográficas y culturales. Estos escritos asumieron en Occidente, desde principios del siglo XVI hasta fines del siglo XIX, diversas formas expresivas: desde la inmediatez de la mirada de las crónicas a la búsqueda histórica de los restos de alguna civilización; desde la identificación de ciertas rutas militares y comerciales a la descripción de la historia natural de los lugares visitados; desde la expedición científica a la inclinación romántica por el exotismo; desde los viajes de colonización a las narraciones de aventuras; desde el relato que informaba de tierras lejanas a un lector que difícilmente llegaría a conocerlas al corresponsalviajero de fines del siglo XIX, entre otras formas discursivas. Se trataba, en todos estos casos, de relatos de viajes orientados a representar las imágenes de un mundo en expansión, de proporcionar mapas de tierras exóticas, o de construir un imaginario del "Otro", dejando constancia de lo vivido en sus encuentros con este. El relato de viajes se convirtió así, al menos en el mundo occidental, en una forma de conocimiento, en la que coincidían la configuración autobiográfica y testimonial como eje de una narración que daba cuenta, de manera descriptiva y con gran rigor en la información, de las observaciones realizadas - de la manera más objetiva y veraz posible- por un viajero -informante y protagonista de los hechos- a partir de su experiencia en lugares lejanos y desconocidos. Se trataba de relatos de viajes en las que se plasmaba una sola mirada y una sola voz: la del viajero europeo. Tendrían que pasar muchas décadas antes de que emergieran contrarrelatos, que resquebrajaran, desde adentro, la visión hegemónica de estas narraciones coloniales e imperiales. Por otra parte, ciertamente, no puede dejar de reconocerse, que aun siendo relato el relato de viajes un género referencial, al existir en su construcción una selección de momentos y escenarios, así como un cierto ordenamiento jerarquizado de los sucesos, dicho relato no podría haber estado ajeno a la fabulación. En palabras de César Aira al respecto: "Los viajes eran un relato antes de que hubiera relato: ellos sí tenían principio y fin, por definición: no hay viaje sin una partida y un regreso. La estructura misma del viaje ya es narrativa. Y como salir de la realidad cotidiana ya tiene algo de ficción, no había que inventar nada, lo que permitía inventarlo todo" (Aira, 2001:2). 


\section{Y después, del espacio a la subjetividad}

En la actualidad asistimos, sin duda, a la proliferación del género de la literatura de viajes. Ello no es casual, en el marco de las migraciones y desplazamientos que, por razones políticas y/o económicas, caracterizan al paisaje contemporáneo poblado de figuras en tránsito o desplazadas, y que problematizan las nociones de pertenencia y arraigo. En otras palabras, en lo que Edward Said ha Ilamado "una condición generalizada de desarraigo", en la que "hace falta muy poco para que el arraigado se vea arrancado de sus raíces y para que el feliz y sosegado pierda su lugar al sol" (Wiesel, 1991:19). Por otra parte, el relato de viajes ha asumido nuevos aires, en el entorno de la crisis del positivismo y de la definición estricta de los géneros, así como de las transformaciones en las formas de sensibilidad y en las maneras de contar un mundo que reclama nuevas formas de narrarse. El modelo del relato de viajes regido por las reglas que lo caracterizaron entre los siglos XVI y XX -período de expansión y exploración europea como también de construcción de un conocimiento científico que exigía un mandato de verdad y objetividad- ha dado paso a nuevas formas de relatos que, si bien conservan ciertas características de género que le son propias y que lo definen frente a otros tipos de narraciones -como por ejemplo, la relación con la experiencia demostrable, el carácter del narrador como testigo presencial y un efecto de realidad que le dé verosimilitud al texto-, ya no son necesariamente una fuente objetiva de información, sino una mirada que participa y se implica en lo narrado. En esta línea, el actual relato de viajes inscribe la visión íntima y personal del autor-viajero; este aporta ahora una mirada subjetiva e intensa que toma cuerpo en una voz en primera persona, el que ya no se limita solo a narrar el viaje sino que se vuelve parte de él, explicitando, al mismo tiempo, el ejercicio de escritura y privilegiando, más que la descripción, lo que va ocurriendo en el viaje mismo. Más sensual que descriptivo, el nuevo relato de viajes se construye a través de sofisticadas técnicas de elaboración narrativa y de un entretejido de géneros literarios en el que se cruzan la crónica, el ensayo, la ficción, las memorias, la autobiografía, etc., en una errancia estilística que refleja el cruzamiento permanente de territorios e identidades y la incesante transgresión de fronteras del viaje contemporáneo. Quien escribe hoy relatos de viajes, más allá de la narración misma, se convierte él mismo en ese viaje, y simultáneamente, sin excluir el trazado cartográfico, la narración puede ser una excusa para reflexionar en torno a ciertos temas cruciales de nuestra contemporaneidad: la memoria, el olvido, el exilio, el desarraigo, las trazas posible entre los tuétanos de la historia y el presente, el discurrir por la diversidad, la extranjería, la pertenencia, el hogar, etc., en una tonalidad más cercana a las voces que a los paisajes, más interesada en develar las historias mínimas y ocultas de quienes van apareciendo en el viaje que en la cartografía del mismo. Así, por ejemplo, en su libro En la Patagonia (1997), un libro que significó una vuelta de tuerca en el relato de viajes, Bruce Chatwin no se centra en la descripción geográfica de los confines del mundo patagónico, sino que ubica ese espacio como el marco social de una serie de historias individuales y fragmentadas, carentes de una narrativa central y que son narradas a través de pequeños detalles a lo largo de breves capítulos, privilegiando el relato de lo que va aconteciendo en su propia subjetividad. A su vez, Claudio Magris en El Danubio (2004), a través de un relato en el que se mezclan el ensayo, el reportaje y 
la investigación, arroja luz sobre las historias de quienes viven a orillas del Danubio, utilizando a este río como metáfora de los peligros que encierra la persistencia de las fronteras -físicas y simbólicas- en el centro de Europa y su aspiración a la convivencia pluralista entre los pueblos pertenecientes a la civilización danubiana. Peter Handke, en Un viaje de invierno a los ríos Danubio, Save, Morava y Drina (1996), se convierte en testigo de los pequeños detalles cotidianos que se desenvuelven tras la devastadora guerra de los Balcanes. Por su parte, V.S. Naipaul, desde una mirada íntima, relata sus viajes desde su natal Trinidad a Inglaterra y más tarde a la India, África, el Caribe y los países islámicos $(1995,1998,2001)$ bajo la forma de una crónica personal -y en la que está presente también el ensayo, la novela, el reportaje y la autobiografía- examinando con perturbadora lucidez el legado del colonialismo, los efectos perversos del nacionalismo y los peligros del fundamentalismo religioso. En el caso de los reportajes de Ryszard Kapuzinsky (1980, 1987, 2003, 2007), el relato de viajes se entreteje con la crónica periodística y las experiencias personales, y la atención se focaliza en los pequeños detalles imprevistos que se desenvuelven en el marco de los grandes acontecimientos. A su vez, las crónicas de viajes del escritor argentino Martín Caparrós en su libro Una luna (2009), por ejemplo, se mueven en un terreno fronterizo entre el periodismo y la narración personal, la ficción y el ensayo, recuperando las historias singulares y desgarradoras de figuras tan marginales y vulnerables como pueden ser una mujer explotada en la trata de blancas, un migrante musulmán, un pandillero, una víctima del Sida, etc., sobre el trasfondo de una época tan brutal como la nuestra. Y un escritor como G.W. Sebald en Los anillos de Saturno (1995) fusiona el relato de viajes, el ensayo, la autobiografía, el reportaje periodístico, el artículo científico, la poesía, e incluso el comentario de sus lecturas, con fotografías antiguas de lugares, objetos, personas, manuscritos, mapas, etc., elementos todos que contribuyen, según el propio Sebald, a reforzar la "objetividad" del relato, y que aspiran a corroborar la intención del autor a convencer al lector de que lo que se relata es cierto. El relato de Sebald sobre su viaje a pie en 1992 por las tierras recónditas de Suffolk, describe los lugares semiabandonados que va recorriendo, al tiempo que se sumerge a través de su propia óptica en territorios devastados por el tiempo y el olvido para construir sus propios paisajes desde la singularidad de su mirada. Es en esta línea de la literatura de viajes que se insertan los textos de dos escritoras chilenas: Poste Restante (2010) de Cynthia Rimsky, y Quebrada. Las cordilleras en andas (2006) de Guadalupe Santa Cruz.

\section{Las viajeras fracturadas}

Ciertamente, el relato de viajes en Chile ha tenido hitos cruciales en textos como La sombra del humo en el espejo, de Augusto D'Halmar (1959), referido a las travesías del autor por Oriente; en las inolvidables Crónicas de Joaquín Edward Bello $(1954,1966)$ y, sin duda, en parte de la obra de Gabriela Mistral, quien relata en diversos textos su travesía por regiones extranjeras (1978), reconstruyendo también desde la memoria, en su Poema de Chile, sus recorridos por la geografía chilena $(1967,2010)$. Pero Poste Restante -texto que relata el recorrido a saltos por distintas ciudades rumbo a Ulanov, Ucrania, de donde habría emigrado el abuelo paterno de la autora- y Quebrada. La cordillera en andas -relato de un viaje hacia lo más hondo y recóndito del 
paisaje chileno, las quebradas del Norte Chico y Grande de Chile- se encuentran en un registro diferente, planteando temas que se inscriben en los itinerarios más problemáticos de la reflexión contemporánea: el viaje como metáfora para repensar la cultura de nuestros tiempos, el desarraigo como destino del mundo, la compleja relación entre identidad, pertenencia y hogar, el movimiento como desplazamiento entre una morada inicial y la promesa ¿imposible? de una vuelta a casa, las incertidumbres como condición de vida cuando las viejas certeza se quiebran para dar paso a resultados inciertos, el imperativo de repensar tiempos y espacios más allá de la pertenencia única a una cultura, lenguaje o tradición y, ciertamente, el tema de la escritura como viaje (Anzaldúa, 1990; Rushdie, 1991, Chambers, 1994; Yyer, 2000; Magris, 2004; Arfuch, 2005).

Poste Restante, de Cynthia Rimsky, relata el viaje de la autora-narradora por Israel, Egipto, Chipre, Turquía, Ucrania, Praga, Polonia, Austria, Eslovenia, hacia el pueblito de Ulanov, en Ucrania, del que salió su abuelo paterno como tantos miles de judíos que, movidos por la necesidad o la desgracia, habían cruzado el océano en busca de la supervivencia física o espiritual. Pero ahora el viaje, real y metafórico, va en dirección contraria; reproduce, en sentido inverso, la migración. Con la herencia de la historia a cuestas, y recogiendo ciertamente el legado judío de migraciones y diásporas, el viaje reproduce metafóricamente la densidad del viaje original, pero ahora no es el de quien va al Nuevo Mundo a construir una casa, plantar un jardín o ser parte del paisaje nacional en una sociedad que fundía en la "homogeneidad" las memorias de origen, sino el de quien va tras las huellas de un pasado generacional y cultural para abrir los silencios de una historia familiar silenciada, discontinua, fragmentada, difusa en la memoria, cubierta por el polvo del olvido. "Las familias cuyo pasado se remonta a la historia de Chile encuentran objetos que siendo desconocidos están impresos en su memoria, que es también la memoria del país. Para los emigrantes, la historia es una línea trunca" (Rimsky, 2010: 40). El viaje se vuelve la búsqueda de un territorio (no necesariamente geográfico) de pertenencia, entendiendo que la pertenencia no reside necesariamente en un hogar, y que el "hogar" no significa necesariamente pertenencia. Pero en Ulanov no quedan trazas o memoria de los judíos que vivían allí, y en Kiev nadie conoce el apellido del abuelo materno. Ulanov es ahora el territorio del silencio, "un lugar del cual huir y sentir nostalgia" (Rimsky, 2010: 222), como lo es también Chile, visualizado a la distancia como el espacio de la promesa y la desolación. El viaje se vuelve, entonces, un referente elusivo, tangencial, del desarraigo. ¿Dónde está, entonces, el hogar, cuando, como escribe la viajera, "su historia familiar siempre fue una pregunta por el olvido más que una certeza de la cual asirse"? (Rimsky, 2010: 42) ¿Está acaso en el olor de una galleta, el aroma de un guiso, la memoria de los objetos cotidianos, los nombres de las calles o los álbumes de familia? ¿Qué se busca con el viaje? ¿La búsqueda de un pasado, que siguiendo a Salman Rushdie, puede ser "un hogar perdido en una ciudad perdida en la niebla de un tiempo perdido"? (Rushdie, 1991:9) ${ }^{1}$. ¿O la búsqueda de un sentimiento de pertenencia a una comunidad e, incluso, un intento por compartir secretos cómplices entre sus

1 Traducción: G.W. 
integrantes? Guadalupe Santa Cruz, a su vez, hace un viaje tierra adentro, nombrando y describiendo territorios ignotos. Las quebradas-tajos profundos y ondulantes en la tierra, con frecuencia ubicados entre las paredes abruptas de las montañas, por los cuales atraviesan un arroyo o un río pequeño y de escaso caudal, que se encuentran al interior del Norte Grande y Chico chileno, una zona árida de pequeños pueblos aislados que dejan entre ellos vastas zonas vacías. La literatura del desierto, inserta en lo que Patricio Manns ha denominado la "literatura de los espacios abiertos" (Manns, 2002) -en la que es sustancial la relación del hombre con la naturaleza como espacio no civilizado, no corrupto, no seguro, no ordinario, no conocido, y donde queda de manifiesto la desproporción entre la medida del hombre y la grandeza del lugar-, corre paralela a la construcción de un nuevo paisaje teórico-culturaI que asume la morada como un hábitat móvil, es decir, "como una forma de vivir el tiempo y el espacio no como si fueran estructuras fijas y cerradas, sino como fuentes que incitan a una apertura crítica cuya cuestionadora presencia reverbera en el movimiento de las lenguas que constituyen nuestro sentido de la identidad, del hogar y de la pertenencia" (Chambers, 1994:18). Las quebradas son imprevisibles: se puede llegar a ellas por caminos firmes o peligrosos, provocan una sensación de infinito ante su austera belleza. El viaje de Guadalupe Santa Cruz se desliza de sur a norte, hasta llegar al desierto de Atacama, el más árido del mundo, atravesando una diversidad de quebradas que aparecen en el paisaje desértico como pequeñas vertientes subterráneas al fondo de un valle transversal; arroyos que serpentean por el extenso paisaje del desierto; cursos intermitentes de aguas que lo fragmentan y se infiltran en la arena permitiendo levemente la existencia de hábitats para poblaciones humanas. En el desierto de Atacama, como en todo desierto, no hay protección. Incursionar en él es ser siempre un intruso. Metáfora de un espacio en blanco, e incluso irreal, en el que la palabra se ofrece en su libre desnudez, permite imaginar ficcionalmente mundos distintos. Paisaje carente de detalles, obliga a crearlos en la mente. La carencia presente en el desierto, más allá del desamparo que genera, es condición positiva y vital para la escritura. En palabras de Edmond Jabés, el desierto es "el lugar verdadero de la palabra... donde esta tiene carta de ciudadanía en el silencio de las otras palabras" (Jabés, 2001: 83). La tierra incógnita del desierto sugiere lo desconocido, lo prohibido, lo proscrito, lo Otro, extraño y ajeno. No hay en el desierto "un" solo lugar, sino una multiplicidad de paisajes mudables, leves, transitorios. En el desierto -que seduce y fascina- todo se muestra y todo se esconde. En sus horizontes infinitos puede esconder ruinas, fantasmas o trazos de quienes por allí cruzaron. Espacio sin irrigación, o apenas centrado en los oasis, el desierto aparece, en primera instancia, como un terreno de negación, definido por lo que no es o no tiene (agua, vegetación, humedad). Carente de centro, el viaje en el desierto es una travesía discontinua, abierta e incompleta. Así, el desierto puede ser tenso y peligroso, pero también un espacio de mirada irónica y crítica de amplitud insospechada. Puede ser un espacio de fluidez y resquebrajaduras, pero también un ámbito que esconde revelaciones profundas. Imposible de reclamarlo o poseerlo, el desierto es tierra de todos y tierra de nadie. Allí donde el desierto divide, tangencialmente, universos que parecen no tocarse ni cruzarse, las voces se mezclan y los espacios se entrelazan para redefinir las señas de identidad. "Las quebradas son esquinas del desierto donde es posible trocar y mezclarse, son una lengua húmeda de la pampa, su blando 
y abierto declive", escribe Guadalupe Santa Cruz (Santa Cruz, 2006, s/p). El viaje de Guadalupe Santa Cruz por el desierto del norte de Chile se desliza por las quebradas que fluyen entre hendiduras "desmantelando el gesto chileno del viaje longitudinal, a lo largo y no a lo ancho" (Montecino, 2006), rompiendo con la familiaridad de una cartografía nacional que visualiza al país como un largo y estrecho paisaje montañoso que se desenvuelve de norte a sur, casi próximo a caerse al mar, para inscribir un "relato de país" (Jeftanovic, 2012:13) que fluye a través de "abismos horizontales" (Santa Cruz, 2006.s/p).

El relato de este viaje se ubica, entonces, "a contracorriente" de un imaginario cultural centrado en los conceptos de Estado-Nación, territorio e identidad nacional, ampliamente cuestionados a la luz de recientes fracturas y contradicciones de un discurso histórico insuficiente ya para legitimar un proyecto de nación y de identidad nacional sustentados sobre los principios de unidad política y homogeneidad (Montecino, 2003; Portales, $2004,2010)$. De igual modo, recuperar literariamente las quebradas supone volver el rostro a las discontinuidades de un paisaje nacional excluido de un imaginario de país construido a partir de símbolos vinculados a la agricultura y al campesinado del centro del país (Bengoa, 2009), privilegiando una geografía disímil, distinta por su diversidad y lejanía con el resto del país y su pasado común. El relato del viaje a las quebradas nortinas -que no han tenido un gran peso simbólico en la construcción de la identidad chilena- incorpora a la cartografía nacional espacios marginales, y lo hace a través de las fisuras metaforizadas en las quebradas que corren de manera transversal en un país acostumbrado a representarse a sí mismo de norte a sur (Montecino, 2006) de un modo vertical que denota, al mismo tiempo, la verticalidad del poder. El relato del viaje a las quebradas obliga, así, a mirar los perturbadores relieves y "quiebres" del paisaje nacional, rescatando la pluralidad geográfica y social desde el horizonte de la alteridad que habita en las distintas moradas de la nación. "No hay país sino un paraje en cada hendidura" (Santa Cruz, 2006.s/p). El relato de viajes de Guadalupe Santa Cruz otorga visibilidad y presencia a los territorios periféricos y agrestes del norte del país, "franjas horizontales de visión, mirada a la redonda" (Santa Cruz, 2006:s/p). No hay allí "un" solo lugar, ni una sola visión de país, sino una multiplicidad de paisajes marcados por huellas de larga data, en los que se superponen tiempos, atmósferas y lenguajes distintos, a la vez paralelos y disímiles. "Se cruzan cuerpos en las quebradas, ventoleras inversas que descolocan, chiflones y cauces, abismos horizontales: la promesa de otras rutas" (Santa Cruz, 2006: s/p).

Ambos relatos de viajes, construidos desde los intersticios de la biografía y la historia, narrados desde los fragmentos de un mundo perdido, desgranados a través de trazos y gestos mínimos, constituyen una experiencia estética y vivencial que da cuenta de un viaje en busca de una memoria genealógica e histórica que va encontrando, en su propia errancia, otras historias y otras memorias. Estructurados en un mosaico de fragmentos narrativos -al parecer única forma de aproximarse a una totalidad perdidacon grandes espacios en blanco -en un guiño (casi) explícito a Benjamin, para quien la posibilidad de acceso a la experiencia verdadera solo es posible a través del fragmento-, ambos relatos dan cuenta de un viaje 
inconcluso, contrapuesto a cualquier simbología del absoluto. Escritura fisurada en su linealidad -porque solo lo fragmentario puede dar cuenta de la escisión y precariedad-, construida en los huecos y las ausencias de un viaje que se desgrana desde el lado de lo secreto a fin de develar lo celosamente guardado y decir lo que no se puede decir, Poste Restante y Quebrada. La cordillera en andas constituyen la narrativa de un viaje que encuentra en la carencia su marca de origen, avanzando a través de las experiencias cotidianas en búsqueda no de lo público sino de lo privado. Ya en los títulos esto aparece expresado. "Poste restante" es el servicio de correos que permite a un viajero, o a quien no tiene domicilio fijo, recibir cartas en una oficina postal. Pero las cartas -marca de intimidad- no siempre le llegan a la viajera-autora o no son retiradas. "Poste restante", que podría ser el refugio donde detenerse, aferrarse a lo amado y conocido, no lo es. Las cartas serán devueltas a sus remitentes. El punto de llegada -una "morada"- no existió. Las quebradas, a su vez -escisión, herida, fisura- denotan algo fragmentado, interrumpido en su continuidad. En este sentido, ambos relatos de viajes no solo se afirman, inicialmente, en un lugar de interrogación y duda constante a través de una escritura del fragmento -subversivo en sí mismo-, sino que parten de una subjetividad herida: la de la no pertenencia cabal.

Imposibilitada de ofrecer una imagen completa de sí misma, también en su alteridad, permite develar lo oculto y lanzar una mirada lúcida sobre la opacidad de lo establecido. Se trata de relatos de viaje que transcurren en una suerte de nomadismo estilístico en el que se conjuntan, desde una mirada intimista, los (desdibujados) trazados cartográficos, la biografía, la historia, testimonios, relatos orales que dan paso a las voces de otros a través de sutiles estrategias literarias.

\section{El desdoblamiento del viaje: las inscripciones gráficas}

Poste Restante y Quebradas. La cordillera en andas son relatos de viaje construidos y diseñados simultáneamente con un lenguaje narrativo y otro gráfico-visual, como si este último cumpliera el imperativo de inscribir, de otra manera, la experiencia del viaje. En el primer caso, dibujos, fotografías de documentos, postales, mapas, guías de viaje, recortes de periódicos, notas personales, cartas, apuntes en una agenda, etc., recogidos a lo largo del viaje, se intercalan en el texto y lo comparten. La vida se traslada a la escritura. En el segundo texto, fotograbados hechos a partir de fotografías digitales en blanco y negro tomadas durante el viaje, dan testimonio de la que la narración puede fluir a través de otro lenguaje: el visual. En este caso, lo relatado se graba en la tinta del grabado. Se trata, en ambos casos, de un doble viaje: el geográfico y el textual, y de un doble relato: el narrativo y el gráfico. Texto y visualidad se mueven, así, entre dos polos que apropiándose de distintos lenguajes que se contemplan de reojo, alumbran sutilmente los paisajes y las voces que van apareciendo en la travesía. Cada uno de estos lenguajes, en su propio código, visibiliza lo que queda oculto en el "otro" relato, generando la posibilidad de "otra" lectura. El soporte canónico de la narrativa se fragmenta: junto a él se inscribe el soporte gráfico. "Esta es la promiscuidad deseada, es esta. Trasladarme. Llevar la mancha de un lado a otro dejando huellas de reconocimiento, distante de aquí a allá, disuelta en 
todas las tintas en que aparece lo escrito, lo visto", escribe Guadalupe Santa Cruz al respecto (Santa Cruz, 2006: s/p).

Entre ambos lenguajes se transita en una provisionalidad mutua, dando cuenta de la precariedad tanto de la experiencia del viaje como de su memoria. "Traslado el signo de un soporte a otro para multiplicar el goce de la escritura", escribe la autora de Quebrada. La cordillera en andas, aun cuando los grabados sean trazos desdibujados que capturan paisajes áridos y desgastados, y cuyo proceso de elaboración es inexacto. "Calco los pies de abra, la cabrías. Modifican levemente su forma según el pulso". Y agrega: "El paisaje no es la imagen. El paisaje es el deseo, hoy, de lijar" (Santa Cruz, 2006: s/p).

Ambas viajeras se sitúan, así, en un espacio intermedio -un in between- entre dos mundos, dos lenguas; es decir, en tierra de nadie, donde la narración del viaje encuentra un espejo en la imagen, y viceversa. En Poste Restante, la narración constituye un trabajo lingüístico sobre la experiencia; en el libro de Guadalupe Santa Cruz, la narración es indicio y materialización referencial de lo narrado. En este registro heterogéneo entre dos lenguajes, la identidad se desdobla (aunque sin perder su voz). Cynthia Rimsky esculpe las palabras en el texto, al tiempo que la experiencia estética de las imágenes va ofreciendo la "otra" clave de su viaje: la fotografía del álbum (equívoco) que da origen al viaje, mapa de las estaciones del Metro de Londres, listas en las que aparecen palabras en dos idiomas, papeles en los que está escrito en alfabeto cirílico el destino final de la travesía, copias de cuentas y gastos, las cartas no recibidas, reproducciones de guías de viajes, o una fotografía de la desolada Ulanov, donde no queda memoria de la familia paterna.

Guadalupe Santa Cruz escarba de manera discontinua el lenguaje al punzar con instrumentos cortantes los grabados que, a partir de las fotografías, va creando en la superficie rígida de la matriz de grabado como espacio de creación -simultáneamente, matriz de gestación que da vida- al tiempo que los grabados van constituyendo un relato paralelo, igualmente punzante, de una palabra precaria que no puede representar de manera cabal a las quebradas nortinas (hondonadas, tajos, hendiduras). Tampoco puede dar cuenta de la dificultad de inscribir la memoria del pasado reciente en una sociedad tan fisurada, herida y dividida, como la chilena (en particular a partir de la década de los setenta). "Hago uso del taladro y su rueda de aspas abrasivas... preparando un espacio para aquel paisaje por venir que puja en mis muñecas", escribe esta narradora (Santa Cruz, 2006, s/p). En ambos casos, la disposición textual y gráfica rompe con una narración racionalizadora y lineal del texto, desconcertando al lector y evidenciando la provisionalidad, flexibilidad y maleabilidad de ambos lenguajes en su alteridad mutua. En este moverse "entre lenguas" (Braidotti 2000) -que refleja el cruzamiento permanente de territorios e identidades y la incesante transgresión de fronteras del viaje contemporáneo-, la "condición nómada" (Braidotti 2000) de los relatos de viajes aquí mencionados anula la (supuesta) estabilidad imaginaria de una identidad del "yo" y la hegemonía de un lenguaje único, históricamente de carácter patriarcal (Guerra, 2007), liberando la actividad del pensamiento del yugo del dogmatismo falocéntrico (Braidotti, 2000:36). 


\section{Los relatos de viajes rompen el silencio}

Quien viaja mira, recuerda, narra, grafica. El relato del viaje se presenta, entonces, como una multiplicidad de textos fragmentarios y desdoblados entre el lenguaje textual y el visual, pero también la narración lingüística aparece desdoblada en un relato disperso que multiplica, de manera descentrada y trizada, identidades, miradas y voces, en una aceptación tácita de que ningún sujeto coincide totalmente consigo mismo y de que la identidad narrativa -igualmente fragmentada y desdoblada- solo se puede manifestar a través de múltiples voces: la narradora en primera y tercera persona de Poste Restante, o las nueve pasajeras de Quebrada. La cordillera en andas.

El desdoblamiento evidencia, entonces $-y$ aun aceptando que el que escribe es el que viaja- y siguiendo a Barthes, que "quien habla (en el relato) no es quien escribe (en la vida) y quien escribe no es quien existe" (Barthes, 1970:34), al tiempo que permite un habla desde otro cuerpo, otro nombre, para relatar un viaje discontinuo entre los espacios y tiempos de origen y destino. Ni una ni otra narradora buscan su historia en lo visible, en lo evidente, en lo nítido, sino es las zonas ambiguas, esquivas, e imprecisas; es decir, en los márgenes, donde se puede leer "de otro modo" el pasado.

¿Cómo reconstruir un pasado sostenido por el silencio? se pregunta la autora de Poste Restante. ¿Cómo reconstruir una trayectoria biográfica e histórica cuando media una experiencia de ruptura del bagaje generacional? ¿A través de qué lenguajes llenar los vacíos y superar las fracturas de la memoria? ¿Cómo trazar los puentes genealógicos cuando la filiación ha sido rota abruptamente?

Para Cynthia Rimsky, el pasado es un país ajeno. Su propia historia se ha (des)dibujado por las narrativas e imágenes (silenciadas) de la(s) generación(es) anterior(es). Pertenece a una generación que lleva en sí la cicatriz pero no la herida de la migración, cuya narrativa es confusa, omisa, imprecisa. El viaje se vuelve, entonces, la búsqueda de una memoria protegida por el silencio que nunca fue construida como relato por sus protagonistas, procurando resucitar, excavar, recuperar, reconstruir, inventar o conjurar la casa del pasado. Memoria difusa, imposible de transcribir fielmente, construida desde la distancia, es una memoria "otra", que presupone una relación precaria con el mundo. Su lugar es la "alteridad", y por lo tanto, se ubica en un espacio de riesgo, fragmentario y frágil. El viaje es, por ello, la búsqueda de respuestas frente a la incertidumbre identitaria del sujeto que lo narra. La nieta de inmigrantes emprende el viaje motivada por una necesidad de definición identitaria entre la situación de extrañamiento y la sensación de no pertenencia cultural. El desarraigo, el luto por la partida y la pérdida de la tierra de origen de los abuelos constituyen parte de la herencia que carga, y el viaje es, en esta línea, el intento por descifrar los enigmas del pasado, el gesto de la ¿imposible? recuperación de un lazo ya roto.

El relato del viaje es el rehacer una historia de ausencias, olvidada y borrada. Crónica de una travesía en sentido inverso, motivada ahora no por una trashumancia quizá indeseada o por un destino histórico de pérdidas y abandonos, este viaje "al revés" intenta retornar a los orígenes en un trazado 
de líneas cartográficas que dibujan paisajes, voces y retratos itinerantes y efímeros, para reconstruir una historia real pero también inventada. Se trata de mirar hacia atrás, escribir y recorrer la historia en sentido inverso. En el empeño por encontrar la propia historia, el viaje no es lineal sino múltiple, poblándose de una multiplicidad de "historias de otros" reconstruidas a través de imágenes e indicios dispersos, trazos mínimos, gestos, huellas, pequeños ritos de lo cotidiano en una errancia en la que la viajera se interna a la deriva por callejuelas olvidadas, a contracorriente de la "dirección única" de las grandes avenidas (en el sentido benjaminiano).

El viaje -movimiento interior, íntimo- tiene su ritmo propio, dado por el encuentro con las historias que afloran. Al recuperar los relatos olvidados, se potencia el poder de la palabra en un trabajo estético que se repliega sobre el lenguaje mismo, pero, al mismo tiempo, la estructura narrativa impide una clausura o cierre, y la viajera se afirma, paradójicamente, en un lugar de interrogación y duda constante, en la tensión entre experiencia y extrañamiento. La memoria se construye en el cruce permanente entre los detalles minúsculos de la biografía, los trazos de vida de los "otros" y el peso de la historia colectiva y familiar, recogiendo en todos los casos fragmentos del pasado para armar el rompecabezas de una memoria sin recuerdos.

El relato del viaje de Guadalupe Santa Cruz intenta recuperar la memoria no solo de la geografía de las quebradas, desdibujadas y polvorosas, sino de los escombros de vida sepultadas en sus hendiduras, restos de un pasado enterrado $-o$ al menos suspendido-, pero que quienes viven allí no han olvidado y se esfuerzan por armar, como un rompecabezas siempre inconcluso."En el pueblo y en el paisaje conozco un sendero que no posee trazado" (Santa Cruz, 2010: s/p). En las quebradas habitan relatos que han sido y siguen siendo historia, aunque la memoria de quienes la portan esté "quebrada". El viaje de Guadalupe Santa Cruz devela las franjas oscuras de parte de la historia y la memoria del país, y desempolva las sombras y discontinuidades de una geografía secreta que perdura en los márgenes de una historia "oficial" (dictatorial y postdictatorial) centrada en un relato de transparencia, éxito, dinamismo y eficiencia, pero en el que "a la vista de los valles transversales que traen agua frondosa y van a dar al mar... los padres, cuando aún se hallan vivos, se desperezan. Se despiertan de la siesta, de la enfermedad o del olvido y les dicen a sus herederos y herederas que ellos no recibieron nada, así como ellos, sus descendientes, no recibirán nada... Los descendientes de los descendientes, que no han recibido nada, lo saben" (Santa Cruz, 2010: s/p).

La viajera se interna -ajena al reloj- en el paisaje abierto de las quebradas para fisurar el monopolio de la "voz única", para romper el silencio de personas y situaciones usualmente condenados a la penumbra, y también para dibujar el perfil "quebrado" de un país que ha silenciado la memoria en torno a la violencia del pasado reciente, y que aun, con manifestaciones distintas, sigue presente. "Juvenal Santibáñez entiende la curiosidad que me mueve, él remueve la tierra y construye mapas de una historia que sigue sucediendo", (Santa Cruz, 2006). El viaje se vuelve, así, una arqueología de la memoria. Su narración es, al mismo tiempo, la exploración hacia un pasado que ha quedado fuera del relato oficial del país. Quebradas. La cordillera 
en andas resquebraja toda coherencia -discursiva e histórica- invocando lo residual, reconstruyendo un pasado marcado por quiebres y fracturas, poniendo atención a los rostros y voces de quienes, con callosidades en los pies, perturban la "historia oficial". Porque "el vacío de los desiertos siempre está rodeado por las historias perdidas" (Ondaatje, 1997:17), y "nadie habla, solo los que vienen de afuera" (Santa Cruz, 2006) El relato de viajes de Guadalupe Santa Cruz no solo se apropia de las piedras y las escasas aguas del desierto, sino también de las memorias no aquietadas, de los relatos interrumpidos de un joven de rodillas enclenques a cuyo padre le fue amputada una pierna y cuya madre era una fugitiva. Se apropia de las subjetividades heridas de quienes viven en las quebradas, haciéndose cargo de la memoria de los otros; compartiendo los recuerdos, la memoria y la experiencia colectivos entretejida con la propia. ¿Quiénes son los habitantes de las quebradas? ¿Cuáles son sus historias? ¿Cuáles son las memorias negadas a los vencidos? ¿Qué es "lo que no se puede decir" y que intentan decir los vacíos de las quebradas? ¿Qué imágenes de la devastación histórica se pueden encontrar bajo la apariencia de normalidad?

Al rescatar los relatos que se inscriben en los tajos, la viajera -a través de una mirada íntima- "quiebra" el silencio del país. Al darle sonoridad a las huellas recónditas de quienes habitaron y siguen habitando las hendiduras de agua en el desierto, contrapone la voz íntima ante la hegemonía de las instituciones y el poder. Las imágenes son los rastros, las ruinas del tiempo, en un país marcado por las ausencias. Ellas testimonian lo desaparecido, el desarraigo. No hay trama, no hay protagonistas, no hay un centro: solo el lenguaje discontinuo, astillado, herido, intersticial. El hogar puede ser la nostalgia, el destierro, la metáfora del despojo, el sitio emblemático que resguarda en la lejanía lo que se puede perder inexorablemente; la memoria que se lleva a través de territorios sin fronteras, reconocida como tal en su pérdida. "Yo que no he podido ser del paisaje, me es prestado, y los lugares me persiguen, me hacen falta" (Santa Cruz, 2006:s/p).

\section{Llegar o no y adónde}

Los viajes relatados en Poste Restante y Quebradas. La cordillera en andas están atravesados por la incompletitud, la falta, la ausencia, la precariedad, la orfandad, identidad fracturada. "Viajar es, por supuesto, la confesión de la impotencia: ir a buscar lo que te falta a otros lugares" (Caparrós, 2009:16). En ambos casos, el viaje surge de una situación de carencia, de una herida, de una precariedad existencial, del desmoronamiento de un cobijo protector, de una historia invisibilizada, tan propia de la historia femenina (Kirkwood, 1987). Se trata de viajes sin destino fijo; travesías por desviaciones, ajenas a la cronología del tiempo, dotadas de un ritmo propio e íntimo. La pérdida y la necesidad de relatar esa pérdida desencadenan el viaje y su relato. Las narradoras son sacadas de sus moradas y expulsadas a una errancia en la que la extranjería será la única residencia. Sobre el desgarramiento de la pérdida inicial, de la pérdida del pasado, de la no existencia de la plenitud, desde el desvalimiento, se buscan los orígenes. La enunciación está dada desde el "fuera de". Desde una ausencia en la que se inicia y se reconstruye el viaje, desde una condición de no pertenencia y extranjería radical. El viaje es un romper amarras, despoblar lo conocido, ubicarse "desde el otro 
lado". El relato se constituye en una manera de habitar el mundo desde los márgenes, desde un margen lateral, errante, no fijo. Surge como un "ser arrojadas al mundo", como una dispersión elegida sabiendo, sin embargo, que el viaje constituye un paréntesis y a la vez un pasaje -y un extravíoentre los espacios y tiempos de origen y destino. "No doy con el Loa, un río misterioso, aunque su misterio sea sencillo...", escribe Guadalupe Santa Cruz (Santa Cruz, 2006:s/p). Y es en estos territorios a la intemperie, carentes de toda certeza, donde se halla la posibilidad de imaginar lo que todavía no es. El hogar se convierte, en este sentido, en un permanente "fuera de lugar", en un allá/entonces en contraposición a un acá/ahora. Pero ni siquiera apropiándose el acá-ahora las heridas del desarraigo logran sanar.

En Poste Restante la memoria de la historia familiar se ha perdido en el silencio y la narradora no sabe descifrar ya la lengua de los abuelos. Por otra parte, la pertenencia al país de origen, Chile, es una "línea trunca" que se debe imaginar o reconstruir. El texto constituye, en este sentido, un relato de viaje-ensayo-narrativo sobre el significado de la pertenencia, el desplazamiento y la pérdida, sobre el hogar como espacio de la vulnerabilidad, sobre el pasado como un campo atravesado por continuidades y discontinuidades. La mecha que gatilla el viaje es el descubrimiento casual de un álbum de fotografías, que lleva en la portada un apellido casi similar al de la autora. El álbum, con fotos de una familia de vacaciones en algún lugar de Europa y que difícilmente tendría algo que ver con la familia de la narradora, son fotos que hieren y resuenan entre las ruinas de la genealogía perdida. Vestigios de algo irrecuperable, irremediablemente perdido, las fotos son el registro de la ausencia. Fragmentos inconexos sin pasado ni presente, tomadas al azar, las fotos evocan un pasado que solo reside en ellas. Son un rompecabezas que ciertamente no corresponden a la carencia primigenia de la viajera, pero que le permiten iniciar el viaje y construir el relato de la búsqueda del verdadero origen de su historia, aunque sea a partir de fragmentos que no le pertenecen. Las fotos es lo único que ha quedado de esa familia desconocida. En su cotidianeidad tienen un aire familiar, abren el camino a un pasado casi irreal; dejan en suspenso lo que podría haber sido su propia historia. Pero si toda construcción genealógica es una interpretación, también lo es el álbum de fotos.

Las fotografías, en palabras de Susan Sontag, pueden ser "recortadas, retocadas, adulteradas, trucadas" (Sontag, 2006:14). En tanto interpretación - desde un ángulo- de la realidad, son una inagotable invitación a la conjetura. Al no ser una calca real del mundo son, por tanto, también inexactas. El viaje se origina entonces desde el equívoco y la falta. "Al momento de encontrar el álbum de fotografías en el mercado persa había planificado un viaje a Ucrania. Como su interés no era encontrar parientes o el nombre en una tumba, decidió que buscar el origen de las fotografías podía ser un destino tan real como el otro" (Rimsky, 2010:44).

En el relato las fotografías no aparecen mediadas por el ojo de la escritora, sino que son, al mismo tiempo, una presencia y una ausencia, un viaje dentro de otro viaje, un secreto dentro de otro.¿Qué silencios se ocultan tras ellas? Más allá de que la fotografía actúe como registro, evidencia y documento, es decir, como representación de "lo que ha sido", ellas constituyen también 
"textos" conjeturales de múltiples significados. Las fotos en sí no producen narrativa; son mudas. Al contemplar las fotos del álbum familiar, la narradora no solo las "lee" como rastros, vestigios y huellas de la historia, sino como una vía para encontrarse con la propia subjetividad.

En esta línea, una revisión cuidadosa del álbum familiar la lleva a concluir que el propio álbum -una presencia objetiva- está llena de dudas, de silencios, de figuras fantasmales que exigen una explicación, pero que al mismo tiempo la fotografía, que certifica y testimonia, abre espacio para la interpretación subjetiva (e incluso para la ficción). En esa zona incierta entre realidad y representación narrativa queda abierto el ámbito de la conjetura. Las fotos exigen ser contadas y la viajera, al quedar atrapada en su contemplación, persigue en el viaje los trazos fugitivos de esas fotos "que no son", pero que desde su alteridad la incitan a un viaje incierto y precario, elaborado sobre la pérdida, cuyo relato no será sino resistir al extenso e inquietante territorio del olvido.

El viaje de Guadalupe Santa Cruz se inicia también a partir de una pérdida. "El viaje ensucia, no se sabe cómo. Tal vez los baños sin espejo, tal vez estar lejos de todos: los abanicos de servilletas de papel dispuestas en copas de aluminio, las distintas barras de los buses y las micros, las ventanas abiertas y las ventanas cerradas... no se sabe qué es lo que se adhiere y no puede ser retirado" (Santa Cruz, 2006:s/p). La viajera, al partir pierde su nombre y el cobijo de lo conocido. También las distancias pierden su nombre. "Recorro distancias sin nombre, habito por largos instantes un espacio que no se llama hasta tropezar con palabras" (Santa Cruz, 2006.s/p). Carente de centro, el viaje se vuelve una travesía discontinua, abierta e incompleta, que desarma sus propios términos de referencia a medida que el punto de partida se pierde en el camino. El viaje está marcado por un vacío inicial, marcado por la interrupción; un sujeto fragmentado emerge de una experiencia de quiebre histórico en un país en el que persisten las ausencias. "Un niño sin madre en Pichasca debe herrar los animales y hacerlos pastar, cosechar la uva de mesa en los parronales. Tiene las rodillas enclenques porque la falta de madre se aloja allí" (Santa Cruz, 2006.s/p). El vacío reclama, entonces, ser llenado con la narrativa del viaje, con la memoria de una travesía que intente repararlo como señal de duelo. El relato del viaje crea entonces, en su doble lenguaje, lo que no puede recuperar; imagina lo que no puede recordar. "Lo que me ata al grabado es el error, nada en él es definitivo. Una equivocación es punto de partida". (Santa Cruz, 2006.s/p)

Pero el viaje, aunque sea un gesto desesperado por conocer el origen y por restituir el vacío de la fractura, será incompleto, y su relato guardará siempre relación con el desarraigo, la añoranza, el dolor. ¿Cómo buscar, o encontrar, la memoria entre las ruinas? Ulanov es ahora el territorio del silencio, "un lugar del cual huir y sentir nostalgia", como lo es también el país de origen, Chile, horizonte de ninguna Itaca. Las fotos habían sido el mapa inicial para encontrar un lugar no conocido, pero a menudo imaginado. Pero al Ilegar allí, la autora-narradora encuentra el crepúsculo final, al tiempo que Chile es, a la distancia, el espacio de promesa y desolación. Y, aun cuando las quebradas "sean las promesas de otras rutas" (Santa Cruz, 2006:s/p), su viaje no será para llegar sino para seguir la travesía como resistencia a 
las resquebrajaduras. Siempre habrá algo de inacabable en este viaje a las quebradas, un zigzagueo que se dirija hacia sendas abandonadas o hacia itinerarios igualmente frágiles. En cualquier caso, Poste Restante y Quebradas. La cordillera en andas nos relatan un viaje como zona del deseo: ir a algún destino, regresar y narrarlo. Esencia, finalmente, de toda literatura de viajes.

\section{Obras citadas}

Aira César. "El viaje y su relato". El País, 21 de junio, 2001.

Anzaldúa Gloria. Borderland. The New Mestiza. San Francisco: Aunt Lute Books, 1990.

Arfuch Leonor (comp.). Pensar este tiempo. Espacios, afectos, pertenencias. Buenos Aires: Paidós, 2005.

Barthes Roland. Análisis estructural del relato. Buenos Aires: Tiempo Contemporáneo, 1970.

Bengoa José. La comunidad fragmentada. Santiago: Catalonia, 2009.

Benjamin Walter. Dirección única. Madrid: Alfaguara, 1987.

Braidotti Rosa. Sujetos nómadas. BAires: Paidós, 2008

Caparrós Martín. Una luna. Barcelona: Anagrama, 2009.

Chambers Ian. Migración, cultura, identidad. Buenos Aires: Amorrortu, 1994.

Chatwin Bruce. En la Patagonia. Barcelona: Muchnick Editores, 1997.

D'Halmar Augusto. La sombra del humo en el espejo. Santiago: Nascimento, 1959.

Dorfman Ariel. Memorias del desierto. Buenos Aires: Editorial del Nuevo Extremo, 2005.

Edwards Bello Joaquín. Crónicas. Santiago: Zig-Zag, 1954. Nuevas crónicas. Santiago: Zig-Zag, 1966.

García-Huidobro Beatriz y Jeftanovic Andrea (editoras). cl. Textos de frontera. Santiago: Ediciones Universidad Alberto Hurtado, 2012.

Guerra Lucía: Mujer y escritura: fundamentos teóricos de la crítica feminista. México: UNAM, 2007.

Handke Peter. Un viaje de invierno a los ríos Danubio, Save, Morava y Drina. Madrid: Alianza, 1996.

Huyssen Andreas. En busca del futuro perdido. Cultura y memoria en tiempos de globalización. México: FCE, 2001.

Jabés Edmond. Del desierto al Libro. Córdoba, Argentina: Alción Editora, 2001. Kapuscinsky Ryszard: Ébano. Barcelona: Anagrama, 2003. . El emperador. México: Siglo Veintiuno Editores, 1980.

El imperio. Barcelona: Anagrama, 2007.

. El Sha o la desmesura del poder. Barcelona: Anagrama, 1987.

Kirkwood Julieta: Feminarios. Santiago: Ediciones Documenta, 1987.

Magris Claudio. El Danubio. Barcelona: Anagrama, 2004.

Utopía y desencanto. Historias, esperanzas e ilusiones de la modernidad. Barcelona: Anagrama, 2001.

Manns Patricio: "Chile, por una narrativa de los espacios abiertos", en Kohut Karl y Morales Saravia José: Literatura chilena hoy. La difícil transición, Madrid: Iberoamericana/Vervuert, 2002.

Mistral Gabriela: Poema de Chile. Santiago: Editorial Pomaire, 1967. Gabriela anda por el mundo, Selección y prólogo de Roque Esteban Jarpa, Santiago: Editorial Andrés Bello, 1978. 
Montecino Sonia (comp.). Revisitando Chile. Identidades, mitos e historias. Santiago: Publicaciones del Bicentenario, 2003.

"La cuenta quebrada(s)", en Santa Cruz Guadalupe. Quebrada. Las cordilleras en andas. Francisco Zegers (editor), Santiago, 2006.

Naipaul V.S. Un camino en el mundo: una historia. Barcelona: Debate, 1995. . India. Barcelona: Debate, 1998.

. El enigma de la llegada. Barcelona: Debate, 2001. . Entre los creyentes. Barcelona: Debate, 1998.

Ondaatje Michael. El paciente inglés. México: Plaza y Janés, 1997.

Portales Felipe. Los mitos de la democracia chilena. Desde la conquista hasta 1925. Santiago: Catalonia, 2004.

Rimsky Cynthia. Poste Restante. Santiago: Sangría Editora, 2010.

Rushdie Salman. Imaginary Homelands. London: Penguin Books, 1991.

Salinero Stella. "Niño ciervo en la pedagogía poética de Gabriela Mistral", en Nomadías, Facultad de Filosofía y Humanidades, Universidad de Chile, junio de 2010, número 11, 2010.

Santa Cruz Guadalupe. Quebrada. Las cordilleras en andas. Santiago: Francisco Zegers editor, 2006.

Sebald G,W. Los anillos de Saturno. Barcelona: Debate, 1995.

Sontag Susan. Sobre la fotografía. Alfaguara, México, 2006.

Wiesel Eli. "¿Quién le teme al lobo feroz?", en "Los emigrantes". Suplemento Mundial de La Jornada, 23 de junio de 1991.

Yyer Pico. The Global Soul: Jet Lag, Shopping Malls, and the Search for Home. Knopf, 2000. 